Vol. XXIV

2018

\title{
FRANCE'S MILITARY IMPORTANCE FOR THE EUROPEAN UNION
}

\author{
Marius PRICOPI, Alexandru Ioan MOTRIUC \\ “Nicolae Bălcescu” Land Forces Academy, Sibiu, Romania \\ pricopimarius@yahoo.com
}

\begin{abstract}
A founding member of the European Union, France is nowadays still considered, alongside Germany, as one of the two ,engines” of European integration. And this applies not only for the economic or social sphere, as France has also played a preeminent role in the historical process of European defence integration. Acknowledging the French contributions to the European defence project, in this paper we subject to analysis the military importance of France for the Union. Using the analysis of social documents and the case study method, we argue that this country's high level of military integration in the European Union is not at all fortuitous, as is not due to impermanent favourable evolutions.
\end{abstract}

\section{Keywords: common defence, European Union, France, military integration}

\section{Introduction}

Defence remains one of the most sensitive areas of European integration. In time, the process had its ups and downs, facing many challenges [1], recording both major successes (the mutual defence clause, the successful conduct of multinational military operations or the Permanent Structured Cooperation), as well as sounding failures (the European Defence Community). But of the many European Union (EU) countries, the part played by France in the military integration process is truly a significant one. As we reason in the following, France has been at the core of defence integration ever since the beginning of the European Communities. Through various initiatives and consistent contributions, France acted as a catalyst for this process, leading by example and with an unshaken enthusiasm.

\section{Methodology}

The research toolbox for writing this paper consisted in the analysis of social documents, as described in a scientific work written by Glenn Bowen [2], as well as the case study method, as presented in a book written by Robert Yin [3].

\section{Landmarks of France's historical involvement in European defence}

France has always played a preeminent part on the stage of European defence integration.

To begin with, just two years after Germany's defeat in the Second World War, France signed (alongside the United Kingdom - UK) the Treaty of Dunkirk; the treaty entered into force on September 8, 1947 and it was meant to discourage a possible future German aggression. Although the treaty did not produce major effects, it is still considered the predecessor of the Treaty of Brussels.

Resulting from an extension of the Treaty of Dunkirk to the Benelux countries (Belgium, Netherlands and Luxembourg), the Treaty of Brussels (1948) [4] allowed 
the subsequent establishment of the Western Union Defence Organisation, which has been one of the first milestones on the path towards a more deep European defence integration.

Then, between the years 1950-1961, France actively promoted the European Defence Community project [5] and the Fouchet Plan [6]. The European Defence Community envisaged nothing less than a strong European army of 100,000 troops, of which 50,000 under French nationality. The army was seen as an assurance against any future German retaliation, and it was to be put under both French military authority and political coordination. As expected by many, the project generated serious opposition from France's allies, and it eventually failed. On the other hand, the no less ambitious Fouchet Plan proposed a Union of States as a counterpart to the newly founded European Communities. In matters of security, the plan advanced the idea of a common defence policy that would somehow keep the power from shifting away from France and towards the entirety of the western states. At the time, the Fouchet Plan was perceived as a competitor to both the European Communities and the North-Atlantic Alliance and was, accordingly, ditched by the French.

A more successful French contribution to the European defence integration process has been the establishment of the FrenchGerman Brigade in 1987, a bi-national military unit with high mobility and enhanced fighting power, which latter evolved in the first European army corps, entitled Eurocorps. France is also a founding member of Eurofor (a rapid reaction land force), Euromarfor (a multinational naval force) and the European Air Group.

Finally, one of the latest landmarks of France's involvement in European defence took place in 2004 through the establishment (alongside Germany and UK) of the European Union's Battlegroups rapidly deployable units that are capable to intervene in the initial phases of an extended military operation [7].

\section{Frances's Leadership in the Present- Day European Defence Integration Process}

For starters, France holds the first position in the European Index of Military Integration. The Index is a scientific instrument that ranks the EU member states in accordance with their level of military integration [8]. The countries are classified in descending order, the first positions being held by the states that are the most militarily integrated in the EU, while the last positions are held by the least thus integrated states.

Then, according to the annual Military Balance, France covered in 2017 no less than $18.9 \%$ of the entire European defence spending (Figure 1). One country alone exceeded this percentage: UK, with $19.7 \%$; Germany was the only other EU member that neared France's performance, with $16.2 \%$, while the following two countries ranked at a considerable difference: Italy with $8.9 \%$ and Spain with $4.7 \%$.

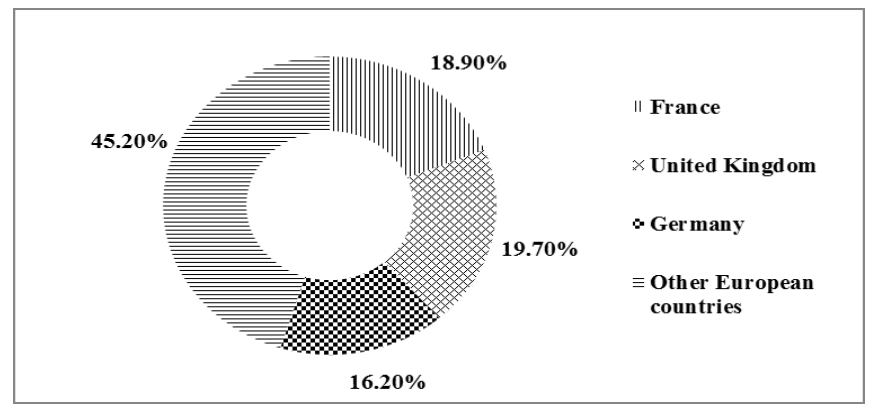

Figure 1: Top 3 European Countries by Defence Spending [9] 
Yet, as has been decided by the British citizens in the June 2016 referendum, the UK is expected to soon leave the EU. Either „soft” or „hard", Brexit will take place at the very latest in March 2019, impacting all the areas of European integration, including the military one. Following Brexit, France will become the top contributor to European defence spending, thus highlighting its irreplaceable role on this matter.

Table 1: Top 7 EU Member States by Number of Active Military Personnel [10]

\begin{tabular}{|c|c|c|}
\hline State & Active military personnel & Rank \\
\hline France & 202,700 & 1 \\
\hline Germany & 178,600 & 2 \\
\hline Italy & 174,500 & 3 \\
\hline United Kingdom & 150,250 & 4 \\
\hline Greece & 141,350 & 5 \\
\hline Spain & 121,200 & 6 \\
\hline Poland & 105,000 & 7 \\
\hline
\end{tabular}

Moreover, of the 202,700 active military personnel, almost 20,000 are deployed or stationed in areas of operation or allied bases around the world, in the most diverse regions, starting from the Arabian Sea, Burkina Faso and Chad, to Somalia, Syria and Ukraine [11].

As an example for other countries, when faced with the budgetary cuts following the 2008-2009 economic crisis, France acted to protect certain key defence sectors, such as intelligence, air or nuclear capabilities. Thus, in order to avoid cancelling equipment acquisitions, Paris responded to the financial pressure by delaying some
Then, France currently has the highest number of active military personnel in the EU, totalling 202,700 men and women (Table 1). As with the military spending, it is followed by Germany $(178,600)$, while UK records a significant negative difference of approximately $25 \%$, with only 150,250 enlisted personnel.

modernization programs, as was the case of Mirage 2000D. Also, to maintain open the production line for the Rafale fighting jets, the French state took the obligation to buy 11 airplanes annually (2011-2013) from the producing company Dassault. The decision proved its merits fast: based on a multi-billion euro contract, India signed up in 2012 to buy 126 Rafale jets, which was a real success for the French defence sector [12].

Considering such policies, it should be no surprise that France has no less than 6 presences in the SIPRI Top 100 Arms-Producing and Military Services Companies (Figure 2).

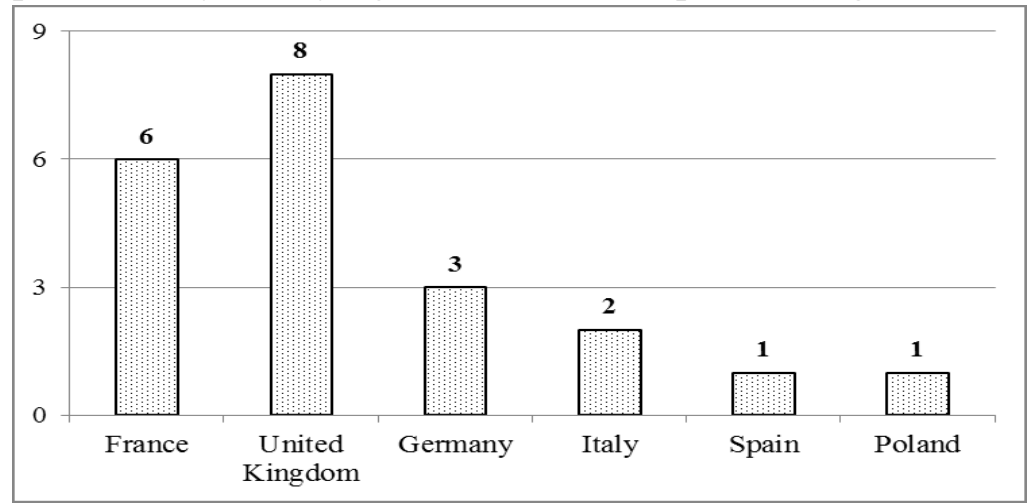

Figure 2: Top 6 EU Member States by Number of Companies in the SIPRI Top 100 [13] 
The top is compiled by the Stockholm International Peace Research Institute, and it ranks in a descending order the most profitable such companies in the world (excluding China). Again, it is only the United Kingdom that has more companies in this ranking (8); but then again, UK will not be part of the EU starting with March 2019, leaving France as the Union's leading country in the SIPRI top.

\section{Conclusions}

France has been calling the shots in the European defence integration process ever since the end of the Second World War. As a signatory of the Treaty of Dunkirk (1947) and the Treaty of Brussels (1948), France has laid the foundations for a future European Union that is relevant not only as an economic and social organization, but as a military one also.

Currently, France leads the European Index of Military Integration - and this should not be a surprise to anyone. After UK, which will soon leave the European Union, France has the most substantial European defence spending, the highest number of active military personnel and the highest number of arms-producing and military-services companies that are present in the Top 100 compiled by the Stockholm International Peace Research Institute.

Therefore, France's military stance in the European Union is not temporary, nor is it due to a favourable provisional context. Actually, in the European defence integration process, France plays an essential and irreplaceable role.

\section{Acknowledgement}

This paper has been elaborated during the sustainability period of the project entitled „Horizon 2020 - Doctoral and Postdoctoral Studies: Promoting the National Interest through Excellence, Competitiveness and Responsibility in the Field of Romanian Fundamental and Applied Scientific Research", contract number POSDRU/159/1.5/S/140106. This project was co-financed by European Social Fund through Sectoral Operational Programme for Human Resources Development 2007-2013. Investing in people!

\section{References}

[1] Ionuț Alin Cîrdei and Lucian Ispas, A Possible Answer of the European Union to Hybrid Threats, Buletinul Științific al Academiei Forțelor Terestre „Nicolae Bălcescu”, no. 2 (44), 2017, p. 71.

[2] Glenn Bowen, Document Analysis as a Qualitative Research Method, Qualitative Research Journal, vol. 9, issue 2, 2009, pp. 27-40.

[3] Robert Yin, Case Study Research: Design and Methods, Sage Publications, 2014.

[4] *** The Brussels Treaty, https://www.nato.int/cps/en/natohq/official_texts_17072.htm, accessed on 7 March 2018.

[5] $* * *$ European

Defense Community Treaty, http://www.lexnet.dk/law/download/treaties/Def-1952.pdf, accessed on 7 March 2018.

[6] *** Fouchet Plan I, https://www.cvce.eu/obj/draft_treaty_fouchet_plan_november_1961en-485fa02e-f21e-4e4d-9665-92f0820a0c22, accessed on 7 March 2018.

[7] European Union External Action, EU Battlegroups, https://www.consilium.europa.eu/uedocs/cms_data/docs/pressdata/en/esdp/91624.pdf, accessed on 8 March 2018.

[8] The detailed methodology and algorithms are described in: Marius Pricopi, Integrarea militară europeană, Sibiu, Techno Media, 2014. 
[9] International Institute for Strategic Studies, The Military Balance - 2018, Routledge, 2018, p. 70.

[10] International Institute for Strategic Studies, The Military Balance - 2018, Routledge, 2018, pp. 102, respectively 108, 118, 161, 111, 148 and 135.

[11] International Institute for Strategic Studies, The Military Balance - 2018, Routledge, 2018, pp. 106-107.

[12] International Institute for Strategic Studies, The Military Balance - 2012, Routledge, 2012, pp. 76 and 78.

[13] Stockholm International Peace Research Institute, The SIPRI Top 100 Arms-Producing and Military Services Companies, SIPRI, 2017. 